\section{Huxley remembered}

Sir Julian Huxley, FRS, one of the best known scientific personalities of our day, died in London on February 14 at the age of 87 .

Huxley was a King's Scholar at Eton and went on to Balliol, Oxford, where he became Brackenbury Scholar and, from 1910-12, a lecturer in zoology. As a undergraduate, he was also awarded the Newdigate Prize for Poetry. At 25, he became Professor of Zoology at the Rice Institute in Houston, but at the outbreak of war returned home and joined the Army Intelligence Corps, serving at the Italian front when the armistice was signed. He returned to Oxford in 1919 as a Fellow of New College and Senior Demonstrator in Zoology, and in 1925 was appointed Professor of Zoology at King's College, London. He also held the office of Fullerian Professor of Physiology at the Royal Institution from 1926-28, but resigned both scientific posts to devote more time to writing and research. His association with the Zoological Society of London as Secretary began in 1935 and lasted until 1942, during which time he helped to develop Whipsnade Zoo. His lifelong interest in Africa resulted in his being a member of the committee of Lord Hailey's 'African Survey' from 1933-38, and a member of the 1944 Committee on Higher Education in West Africa.

Because of his experience and powerful interest in the problems of social evolution and education, the British government persuaded him to become the first Director-General of UNESCO in 1946.

His many publications on animal behaviour, evolution and genetics are too numerous to mention. His Problems of Relative Growth (1932) was a turning point in the study of differential growth of parts of the body, and Evolution, the Modern Synthesis (1948) remains the most comprehensive modern work on this subject. But beguiled audiences of the BBC's 'Brains Trust' programme will remember him best as one of the original panellists, and particularly during the Second World War. Huxley also lent his support to many other institutions-the British Humanist Association, the Family Planning Association, the Nature Conservancy, and so on.

Recognition of his work came from all sectors. Among many were the Kalinga Prize (1953) for popular science writing, the Darwin Medal of the Royal Society (1957) for contributions to the study of evolution, and a Knighthood in 1958.

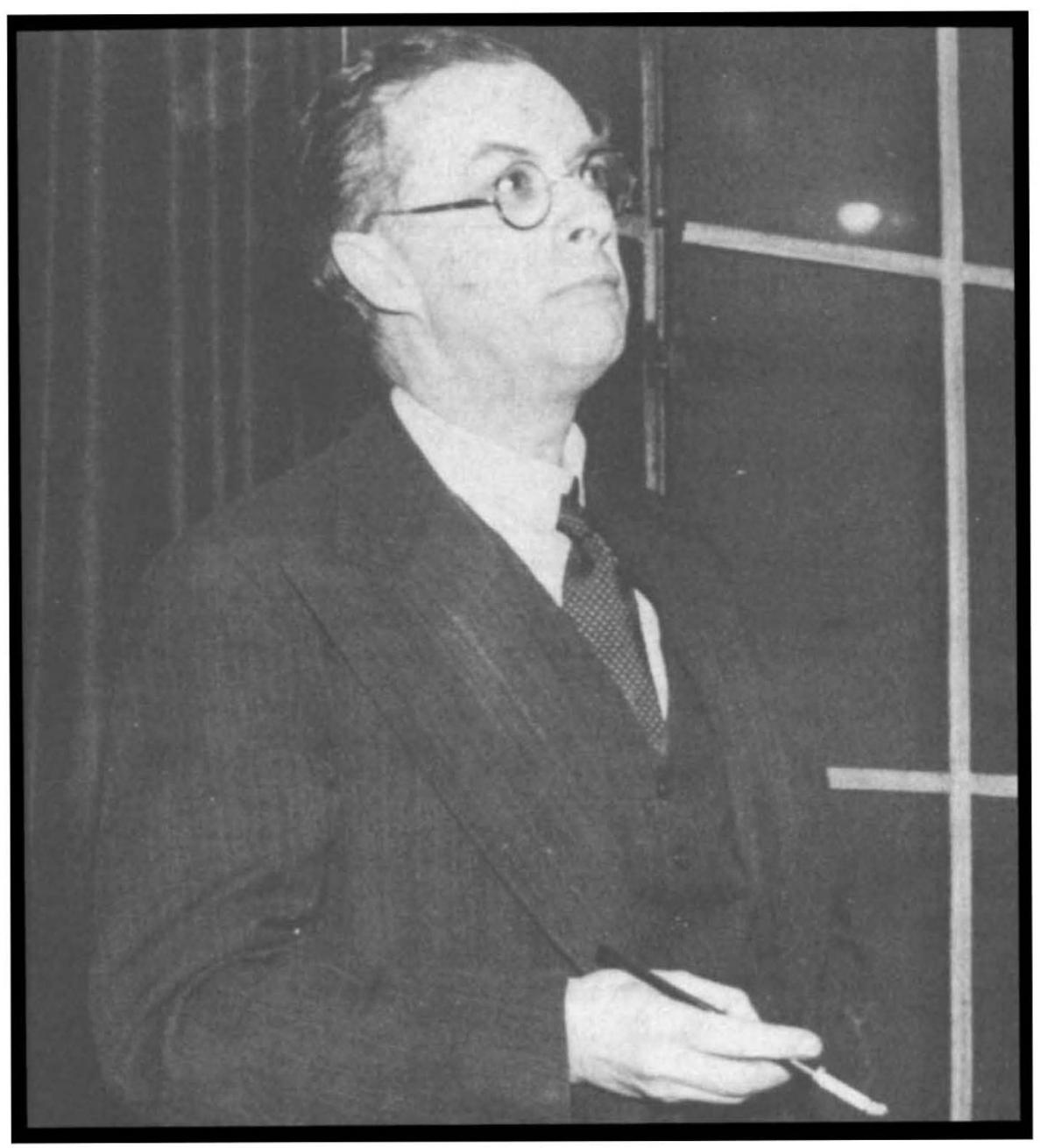

Julian HuXley was only a decade or so older, but he was one of my 'heroes' from the time (1921) when I was starting research in chemical embryology. I never knew him really well and never spent very much time with him, but he was always there as a kind of leading figure "amidst the encircling gloom"; and occasionally our lives impinged strongly on each other. In the 1920 s he was perhaps best known for his work at Oxford on the hybrid control of amphibian metamorphosis. This was outside my field, as I never worked in classical endocrinology, but when the 1930 s came I was extremely interested iri Julian's book on heterogony (or heterauxesis, as it afterwards came to be called) Problems of Relative Growth. Together with Georges Teissier in France I spent a good deal of time in applying these conceptions to the relative growth of the chemical constituents of animal bodies. This turned out to be one of those lines of of investigation which, though interesting in themselves, do not lead immediately to anything further. Quite different was the situation with Julian's Elements of Experimental Embryology, which he wrote with G.R. de Beer in 1934. This was at the beginning of the story of embryonic induction; based on the fundamental experiments of Spemann and his collaborators, it set the stage for a vast amount of work on the 'morphogenetic hormones'. Terminologies change, and organisers tcday might be called 'semantophore macro-molecules', but although such great advances have been made in the study of the hereditary 'books of instructions', the nucleic acid chains, it seems that still today it has not been possible to identify the molecules which pass from cell to cell and determine spacific differentiation destinies. Doubtless messenger RNA is in the picture somewhere. In any case Huxley and de Beer was a stirring overture to a field of experimental morphology still of the highest importance and fascination today.

But neither Julian Huxley nor I were spirits circumscribed by the walls of the laboratory. Both of us were interested in philosophy, religion, artistic creation, history and literature; both of us, like Charles Sherrington and many other scientists, were moved to write poems from time to time. We must retrace our steps, for Religion without Revelation came out in 1927: while my Sceptical Biologist was 1929 of course our standpoints were rather different, though both in a way syn- 